\title{
Evaluation of apple and nut characters of cashew germplasm from Bastar region, Chhattisgarh, India
}

\author{
Vikas Ramteke*, Yaspal Singh Nirala, M.G. Nayak ${ }^{\mathbf{1}}$ and G.S. Mohana ${ }^{\mathbf{1}}$ \\ Shaheed Gundadhoor College of Agriculture and Research Station (IGKV), Kumhrawand, Jagdalpur- 494 001, \\ Bastar, Chhattisgarh, India \\ ${ }^{1}$ ICAR-Directorate of Cashew Research, Puttur-574 202, Dakshina Kannada, Karnataka, India
}

(Manuscript Received: 08-04-2020, Revised: 24-05-2020, Accepted: 30-05-2020)

Keywords: Apple, cashew, evaluation, germplasm, nut characters

Cashew (Anacardium occidentale L.), an important crop of many marginal and small farmers of tribal areas of India, belongs to the family Anacardiaceae. It is a hardy, drought-tolerant tree and comes up well in soils with nutrient constraints (marginal lands). Hence, cashew is considered as the 'gold mine' of the wasteland. Cashew fruit has two distinct parts, viz., the swollen and pear-shaped stalk known as 'cashew apple' and a kidney-shaped nut attached to the lower end of the apple, which is the edible kernel (Ohler, 1979). Cashew cultivation in Chhattisgarh State, India is done primarily aiming cashewnut production. During the year 2016-17, the area under cashew in Chhattisgarh was 13.7 thousand ha with a production of 9.33 lakh tonnes. The bulk of portion of cashew apples goes as agricultural waste once the nut is harvested. The cashew apple is a nutritious fruit available in abundance from April to May in Chhattisgarh and is reported to possess high therapeutic and medicinal properties. It is also useful as a raw material for many industrial applications (Talasila and Shaik, 2013). The juice of the cashew apple is rich in vitamin C $(0.99 \%$ to $1.01 \%)$, minerals (3609.93 \pm $1.15 \mathrm{mg} \mathrm{L}^{-1}$ of potassium, $218.03 \pm 0.22 \mathrm{mg} \mathrm{L}^{-1}$ of sodium, $44.80 \pm 0.11 \mathrm{mg} \mathrm{L}^{-1}$ of iron and $19.75 \pm 0.02 \mathrm{mg} \mathrm{L}^{-1}$ of manganese) and phenolic compounds (45.99 \pm $1.15 \mathrm{~g} \mathrm{~L}^{-1}$ of total polyphenols) (Pascal et al., 2018). The cashew apple is also a raw material for juice, syrup, RTS, pickles, candy, toffee etc. It is estimated that the cashew apple production in the country is about 65 lakh tonnes per year, but less than 10 per cent of it is processed (Saroj et al., 2014). The acrid feeling while consuming fresh cashew apple or cashew apple juice is owing to the presence of tannins $(35 \%)$. Tannins are the anti-nutritional factors that interfere with the assimilation of proteins in the body resulting in non-availability of nutrients. Hence selection of suitable genotypes with low tannin content, low to moderate acidity, high juice recovery and good sugar content in cashew apple will be useful for processing industries and local consumption in Bastar region.

The present experiment was undertaken at Shaheed Gundadhoor College of Agriculture and Research Station (SGCARS), Kumhrawand, Jagdalpur, Bastar, Chhattisgarh during the year 2018-19 in 11 locally collected germplasm planted in the gene bank of AICRP on Cashew, SGCARS, Jagdalpur. Germplasm collections were planted during the year 2002 at a spacing of $7.5 \mathrm{~m} \times 7.5 \mathrm{~m}$. The experiment was laid out in complete randomized design (CRD) with three replications. Ripened cashew fruits were collected from a single tree of each germplasm and divided into three parts, each serving as a replication.

The physical parameters such as apple weight and nut weight were measured using twelve cashew apples from different replication under each

* Corresponding Author: cashewresjagd@gmail.com 
Evaluation of apple and nut characters of cashew germplasm

Table 1. Apple and nut characters of different cashew germplasm

\begin{tabular}{|c|c|c|c|c|c|c|c|c|}
\hline Germplasm & $\begin{array}{c}\text { Apple } \\
\text { weight } \\
\text { (g) }\end{array}$ & $\begin{array}{c}\text { Apple } \\
\text { length } \\
(\mathrm{cm})\end{array}$ & $\begin{array}{l}\text { Apple } \\
\text { width } \\
\text { (cm) } \\
\end{array}$ & $\begin{array}{c}\text { Nut } \\
\text { weight } \\
\text { (g) }\end{array}$ & $\begin{array}{c}\text { Nut } \\
\text { length } \\
(\mathrm{mm})\end{array}$ & $\begin{array}{c}\text { Nut } \\
\text { width } \\
(\mathrm{mm}) \\
\end{array}$ & $\begin{array}{c}\text { Apple } \\
\text { to } \\
\text { nut ratio }\end{array}$ & $\begin{array}{c}\text { Juice } \\
\text { recovery } \\
(\%)\end{array}$ \\
\hline CARS-1 & 41.92 & 37.70 & 37.18 & 5.63 & 25.15 & 17.20 & 7.45 & 69.80 \\
\hline CARS-2 & 59.26 & 52.51 & 41.08 & 5.51 & 30.92 & 17.74 & 10.75 & 64.20 \\
\hline CARS-3 & 65.74 & 52.44 & 44.41 & 8.21 & 38.58 & 24.04 & 8.01 & 71.50 \\
\hline CARS-4 & 33.00 & 38.46 & 23.05 & 5.58 & 28.24 & 19.89 & 5.91 & 61.40 \\
\hline CARS-5 & 77.07 & 42.12 & 31.22 & 7.47 & 31.41 & 22.94 & 10.32 & 60.20 \\
\hline CARS-6 & 46.93 & 48.72 & 36.42 & 7.60 & 34.93 & 25.97 & 6.18 & 63.20 \\
\hline CARS-7 & 33.50 & 50.90 & 34.83 & 6.65 & 30.50 & 23.84 & 5.04 & 72.40 \\
\hline CARS-8 & 105.97 & 63.09 & 48.47 & 12.45 & 39.93 & 25.50 & 8.51 & 81.20 \\
\hline CARS-9 & 86.83 & 42.52 & 41.54 & 9.60 & 32.79 & 24.65 & 9.04 & 63.80 \\
\hline CARS-10 & 84.49 & 59.89 & 47.78 & 10.06 & 38.47 & 28.17 & 8.40 & 77.10 \\
\hline CARS-11 & 87.46 & 54.84 & 49.71 & 8.21 & 36.48 & 26.48 & 10.65 & 68.40 \\
\hline $\mathrm{SE}(\mathrm{m}) \pm$ & 5.82 & 3.49 & 2.62 & 2.34 & 2.23 & 0.77 & 0.31 & 1.41 \\
\hline C.D. $(p=0.05)$ & 17.28 & 10.36 & 7.78 & 6.96 & 6.62 & 2.30 & 0.94 & 4.19 \\
\hline
\end{tabular}

treatment, randomly selected and weighed using a top pan balance. The apple length, apple width, nut length and nut width were measured using a digital Vernier calliper. Juice recovery in percentage was calculated by dividing weight of juice to weight of cashew apple. The total soluble solid of fruit juice was determined with the help of digital refractometer. Titrable acidity was calculated by titrating the pulp extract with $\mathrm{N} / 10 \mathrm{NaOH}$ as per the standard produce suggested by Ranganna (1986). The method of Association of Official Analytical Chemists (Anonymous, 1984) was followed for determination of ascorbic acid, total sugar, reducing sugar and tannin content of fruit juice. Colour and shape of cashew apple were determined as per cashew descriptor (Swamy et al., 1997). The recorded observations were analyzed statistically using analysis of variance (Panse and Sukhatme, 1985).

Significant variation for apple weight, apple length, apple width, nut weight, nut width, apple to nut ratio and juice recovery was observed (Table 1). Significantly superior apple weight was recorded in CARS-8 $(105.97 \mathrm{~g})$ followed by CARS-11 $(87.46 \mathrm{~g})$ and CARS-9 $(86.83 \mathrm{~g})$. Maximum apple length was recorded in CARS-8 $(63.09 \mathrm{~cm})$ which was found to be on par with CARS-10 $(59.89 \mathrm{~cm})$ and CARS-11
$(54.84 \mathrm{~cm})$ while maximum apple width was observed in CARS-11 $(49.71 \mathrm{~cm})$ followed by CARS-8 (48.47 cm). The highest nut weight $(12.45 \mathrm{~g})$ and nut length (39.93 $\mathrm{mm}$ ) was recorded in CARS-8 whereas nut width $(28.17 \mathrm{~mm})$ in CARS-10. The apple to nut ratio plays a key role in the selection of superior types for both nuts as well as cashew apple utilization point of view. The maximum apple to nut ratio was reported in CARS-2 (10.75) which was statistically similar to CARS-11 and CARS-5. Highest juice recovery was observed in CARS-8 (81.20\%) followed by CARS-10 (77.10\%), CARS-7 (72.40\%) and CARS-3 (71.50\%). The physical variations observed for different cashew apple parameters may be due to phenotypic effect. Similar reports of wide variations in physical parameters of cashew apple have been reported by Lenka et al. (1998) and Toppo et al. (2017). However, the extent of juice production was proportional to the weight of the apple and the total cashew apple production of a tree. The present investigation suggests that nut and apple weight are inter-related. The high juice recovery in CARS-8 and CARS-10 is attributed to higher apple weight. Similar variations with regards to juice recovery were reported by Tripathi et al. (2015). 
Table 2. Biochemical characters of apple from different cashew germplasm

\begin{tabular}{|c|c|c|c|c|c|c|c|c|}
\hline Germplasm & $\begin{array}{l}\text { Cashew } \\
\text { apple } \\
\text { colour } \\
\end{array}$ & $\begin{array}{l}\text { Cashew } \\
\text { apple } \\
\text { shape } \\
\end{array}$ & $\begin{array}{c}\text { Total } \\
\text { soluble solids } \\
\left({ }^{\circ} \mathbf{B x}\right) \\
\end{array}$ & $\begin{array}{c}\text { Acidity } \\
(\%)\end{array}$ & $\begin{array}{c}\text { Ascorbic } \\
\text { acid } \\
\left(\mathrm{mg} 100 \mathrm{~g}^{-1}\right) \\
\end{array}$ & $\begin{array}{c}\text { Reducing } \\
\text { sugar } \\
(\%) \\
\end{array}$ & $\begin{array}{c}\text { Total } \\
\text { sugar } \\
(\%) \\
\end{array}$ & $\begin{array}{c}\text { Tannin } \\
\left(\mathrm{mg} 100 \mathrm{~g}^{-1}\right)\end{array}$ \\
\hline CARS-1 & Red & Round & 12.37 & 0.26 & 277.33 & 5.88 & 10.31 & 3.46 \\
\hline CARS-2 & Yellow & Round & 12.19 & 0.30 & 255.33 & 8.41 & 13.50 & 3.12 \\
\hline CARS-3 & Red & Pyriform & 14.03 & 0.33 & 258.67 & 8.31 & 16.71 & 3.25 \\
\hline CARS-4 & Yellow & Pyriform & 13.53 & 0.42 & 247.33 & 7.78 & 14.11 & 3.08 \\
\hline CARS-5 & Yellow Red & Conical to Obovate & 11.49 & 0.32 & 246.33 & 8.20 & 16.72 & 3.11 \\
\hline CARS-6 & Yellow Red & Conical to Obovate & 11.91 & 0.50 & 256.67 & 6.34 & 13.35 & 2.74 \\
\hline CARS-7 & Yellow & Pyriform & 12.44 & 0.36 & 245.00 & 7.99 & 13.50 & 3.65 \\
\hline CARS-8 & Red & Pyriform & 15.15 & 0.23 & 257.67 & 6.42 & 13.14 & 3.12 \\
\hline CARS-9 & Yellow & Pyriform & 13.00 & 0.46 & 242.00 & 7.47 & 10.66 & 3.22 \\
\hline CARS-10 & Red & Pyriform & 11.53 & 0.32 & 236.00 & 6.94 & 12.44 & 2.90 \\
\hline CARS-11 & Yellow Red & Conical to Obovate & 14.65 & 0.51 & 216.33 & 6.32 & 11.40 & 3.45 \\
\hline \multicolumn{3}{|l|}{$\overline{\mathrm{SE}}(\mathrm{m}) \pm$} & 0.28 & 0.02 & 3.44 & 0.37 & 0.44 & 0.08 \\
\hline \multicolumn{3}{|l|}{ C.D. $(p=0.05)$} & 0.87 & 0.06 & 9.36 & 1.11 & 1.31 & 0.22 \\
\hline
\end{tabular}

Study on physicochemical parameters of cashew germplasm (Table 2) revealed that among the 11 germplasm collections studied, four germplasm had red colour apples, four germplasm had yellow colour apples and three germplasm had yellow-red colour apples. Significantly maximum TSS was reported in CARS-8 $\left(15.15^{\circ} \mathrm{Bx}\right)$ and minimum in CARS-5 $\left(11.49^{\circ} \mathrm{Bx}\right)$. The maximum acidity was reported in germplasm CARS-11 $(0.51 \%)$ which was reported on par with CARS-6 $(0.50 \%)$. Significantly lesser acidity was reported in CARS-8 $(0.23 \%)$. The reducing sugar ranged from 5.88 to 8.41 per cent in different collections. The maximum reducing sugar was recorded in CARS-2 (8.41\%) which was found to be at par with CARS-3 (8.31\%), CARS-5 (8.20\%), CARS-7 (7.99\%) and CARS-4 (7.78\%) and lowest in CARS-1 (5.88\%). There was a significant difference in total sugars among the germplasm evaluated (Table 2). The highest total sugar was observed in the germplasm CARS-5 (16.72\%), which was on par with CARS-3 (16.71\%). The lowest total sugar was reported in CARS-1 (10.31\%). Tannin content was highest in CARS-7 (3.65 mg 100 $\left.\mathrm{g}^{-1}\right)$ followed by CARS-11 (3.45 mg $\left.100 \mathrm{~g}^{-1}\right)$ and minimum in CARS-6 (2.74 mg $100 \mathrm{~g}^{-1}$ ) during 2018-19. Similar reports of variation in acidity and sugars were also reported by Lenka et al. (1998) and Toppo et al.
(2017). CARS-8 showed lower values for acidity and medium total sugar level and hence good sugar to acid blend, which is required for taste and flavour of any preserved product.

It is concluded from the experiment that, CARS-8 exhibited superior performance for most of the physical parameters such as apple weight, apple length, and juice recovery. Also, CARS-8 recorded the highest TSS, low acidity and moderate total sugar content. Hence the present studies reveal the scope for utilizing CARS-8 for preparation of beverages and processed products under Bastar region of Chhattisgarh.

\section{References}

Anonymous 1984. Official Methods of Analysis of the Association of Official Analytical Chemists. $14^{\text {th }}$ Edition. Arlington.

Lenka, P.C., Mohapatra, K.C., Mishra, N.K and Dash, S. 1998. Studies on apple characterization of cashew types and their physicochemical characters. Orissa Journal of Horticulture 26(1): 20-24.

Ohler, J.G. 1979. Cashew communication 71. Development of Agricultural Research, Kaninkiijk institutede voor de Tropen, Amsterdam, 131 p.

Panse, V.G. and Sukhatme, P.V. 1985. Statistical Methods for Agricultural Workers. Indian Council of Agricultural Research, New Delhi. pp. 87-89. 
Pascal, A.D.C., Virginie, G., Diance, B.F.T.D., Estelle, K.R., Felicien, A., Valentin, W. D. and Dominique, S.K.C. 2018. Nutritional profile and chemical composition of juices of two cashew apple's varieties of Benin. Chemical Journal 4(4): 91-96.

Ranganna, S. 1986. Handbook of Analysis and Quality Control of Fruits \& Vegetable Products (2nd Ed). TATA MC Graw Hill Publishing Company Limited, New Delhi.

Saroj, P.L., Krishna Kumar, N.K. and Janakiraman, T. 2014. Converting wastelands into gold mine by cashew cultivation. Indian Horticulture 3: 49-56.

Swamy, K. R. M., Bhaskara Rao, E. V. V. and Bhat, M. G. 1997. Catalogue of minimum descriptors of Cashew
(Anacardium occidentale L.) Germplasm Accessions-I. National Research Centre for Cashew, Puttur, Karnataka.

Talasila, U. and Shaik, K.B. 2013. Quality, spoilage and preservation of cashew apple juice: A review. Journal of Food Science and Technology 12: 561.

Toppo, S., Sethi, K., Tripathy, P. and Mukherjee, S.K. 2017. Evaluation of cashew germplasm for physico-chemical parameters and RTS preparation. Trends in Biosciences 10(5): 1261-1265.

Tripathi, P., Sethi, K. and Mukharjee, S.K. 2015. Screening of cashew (Anacardium occidentale L.) types for RTS preparation. Trends in Biosciences 8(12): 3064-3065. 